\title{
Self-Regulation of Learning in Practice Behavior: Exploratory Observation Study of Indonesian Young Badminton Players
}

\author{
Listiyani Siegit \\ University of Edinburgh
}

\author{
Hugh Richard \\ University of Edinburgh
}

\begin{abstract}
Self-regulated learning is an essential skill in maintaining deliberate practice over years, especially for young athletes. Yet, there has not been many studies done on athlete's practice behavior. This study measured the behavioral correlation of self-regulation of learning in Indonesian young badminton players during practice. There were two parts of this study: first, a list of behavioral items was generated from coach interviews with six expert badminton coaches. Second, the list was used to observe players practice behavior during three separate practices and the observed players were asked to complete a self-regulation of learning questionnaire. Eleven badminton players aged 12 to 19 from different divisions participated voluntarily in this study. The observation and questionnaire results showed good self-regulation of learning in badminton players. However, the components breakdown did not match with coaches' concept of selfregulated learning. Players were scored high in effort, yet lacking in metacognitive components which led to less proactive behavior in their learning process. This study highlighted the importance of gaining a complete impression of the players' self-regulated learning skills during practice to develop and maximise their potential.
\end{abstract}

Keywords: self-regulation, individual sports, practice behavior, young athletes, badminton

Belajar mandiri adalah keterampilan dasar untuk mempertahankan latihan intensif selama bertahun-tahun, terutama untuk atlet muda. Namun, belum banyak studi yang dilakukan mengenai perilaku berlatih atlet. Studi ini mengukur korelasi perilaku regulasi diri dalam belajar mandiri pada pemain bulu tangkis muda Indonesia selama berlatih. Penelitian ini terbagi dalam dua bagian: pertama, perumusan daftar butir perilaku berdasar wawancara dengan enam pelatih bulu tangkis senior. Kedua, daftar tersebut digunakan untuk mengamati perilaku berlatih para pemain dalam tiga macam latihan, kemudian para pemain diminta mengisi kuesioner mengenai regulasi-diri dalam belajar mandiri. Sejumlah 11 pemain bulutangkis berusia 12 hingga 19 tahun dari berbagai divisi berpartisipasi sebagai sukarelawan dalam studi ini. Hasil observasi dan kuesioner menunjukkan regulasi-diri dalam belajar yang baik pada para pemain tersebut. Sekalipun demikian, hasil mendetail komponen regulasi-diri tidak sepenuhnya sesuai dengan konsep regulasi-diri dalam pembelajaran yang dikemukakan oleh para pelatih. Para pemain menunjukkan tingkat usaha yang tinggi, namun tidak diimbangi dengan komponen metakognitif yang menyebabkan kurangnya perilaku proaktif dalam proses belajar mereka. Studi ini menyoroti pentingnya pendekatan holistik pada kemampuan belajar mandiri dari para pemain selama latihan untuk mengembangkan dan memaksimalkan potensi mereka.

Kata kunci: regulasi-diri, olahraga individual, perilaku berlatih, atlet muda, bulu tangkis

It is most athletes' ultimate goal to be elites and champions in their competitions. In order to achieve that goal, athletes need to be experts in their own field and maintain high performances. As mentioned by Ericsson, Krampe, and Tesch-Römer (1993) about

This study was supported by the Indonesian Endowment Fund for Education (LPDP).

Correspondence concerning this article should be addressed to Listiyani Siegit, alumna of Faculty of Psychology Universitas Surabaya, Jalan Raya Rungkut Mejoyo, Surabaya 60293. E-mail: listisiegit@ yahoo.com deliberate practice being important for becoming an expert, great discipline and commitment should be invested in the practices in a focused domain from an early age. The complex skills in deliberate practice will not be fully acquired if the athlete does not take control of the process by self-regulating their learning.

Self-regulation itself is a process which enables someone to control their feelings, thoughts, and behavior (Baumeister \& Vohs, 2004). This process develops in every individual and allows them to perform the ap- 
propriate response to a certain situation. Schmeichel and Baumeister (2004) noted that as the key to psychological function, self-regulation plays a significant role for an individual to adapt to their social and physical environment. With regards to performance development, self-regulation helps an individual develop their knowledge and skills effectively which becomes a process to facilitate learning, practice, and competition (Zimmerman, 2006). There is a larger possibility for athletes to maximise their potential by applying self-regulation to their learning process. Zimmerman stated that self-regulation is an essential aspect of sport for young people because this process helps them to learn more effectively. Consequently, self-regulation is associated with accelerated and better performance development to support and improve the opportunity of being selected to be a young professional and elite athlete.

One of the challenges of being an elite athlete is that they constantly need to increase their performance. Nevertheless, maintaining a high level of effort and commitment in the practices over years could be a tough challenge, especially when an athlete is entering their adolescent period. They have to give up many interesting and attractive activities which give them momentary pleasures and spend less time in social encounters in order to keep engaging in their practice sessions (Tedesqui \& Young, 2015; Toering \& Jordet, 2015). It is important for an athlete to be able to maintain their motivation and effort on their increased deliberate practices over time from delayed gratifications around them. Athletes with good self-regulation understand how to accomplish their goals in performance development, stay motivated during the exhausting practices, and take a real step to attain their goal.

Self-regulation process can not directly develop a high level of expertise in an instant, but it is a process to guide individuals to learn skills and acquire knowledge more effectively. Successful individuals are those who adopt a proper regulation strategy after evaluating their weaknesses for achieving their goal (Ertmer $\&$ Newby, 1996). A study on elite and non-elite athletes by Berliner (1994) found that elite athletes showed more flexibility in their planning, sensitivity in specific tasks, and were more reflective of their learning process compared to the non-elite athletes. Promoting self-regulated behavior in a learning context also requires a good understanding of athletes' selfregulated learning types and characteristics. Furthermore, this will also enable the coach to help the athlete learn faster and improve their performance (Hong \&
O’Neil, 2001).

In the learning context, Zimmerman (2006) defined self-regulation as a state where an individual acts as a proactive participant in metacognitive, motivation, and behavior in their own learning process. This means self-regulated athletes can adopt their learning strategy to a learning environment in order to maximise their development. Ertmer and Newby (1996) proposed a model for a metacognitive component of self-regulation which covers: (a) planning how to improve before taking action; (b) self-monitoring actions related to the personal goal; (c) evaluating process and outcome after execution; and (d) reflecting back on the whole process. Furthermore, Toering et al. (2011) suggested that the motivational variable of self-regulated learners is indicated in the motivational belief (e.g. self-efficacy) and motivational outcome (e.g. effort). Thus, metacognitive and motivational processes will be reflected in the behavior shown by athletes, which will then impact their performance.

Self-regulated learning is one of the determinants of practice quality. The interaction between athletes' self-regulated learning ability and their learning environment will affect how they create, discover, and seize the opportunity in front of them. The effectiveness of athletes' learning process management strongly depends on their daily routine practices. For that reason, SRL measurement should be centred on the regular practice session. For example, the SRL process of a soccer player who is aiming to be a professional athlete will be different to those who play at recreational level. Research on the self-regulation of basketball and volley players at an elite level found that they utilise a more effective self-regulation method compared to the non-elite and novice players (Cleary \& Zimmerman, 2001; Kitsantas \& Zimmerman, 2002).

A study was conducted by Toering, ElferinkGemser, Jordet, and Visscher (2009) on the relationship between self-regulation and performance level of elite and non-elite youth soccer players and it showed that players with better self-regulation tend to have better performance. A behavior observation on learning context was conducted to broaden the understanding of effective self-regulation. The follow-up research on elite athletes' self-regulation was done specifically by observing the players' behavior in a practice context (Toering et al., 2011). The study results indicated that self-regulated learning of elite youth soccer players is steered towards taking responsibility for learning and highlighted the importance of measuring behavior to understand players' 
self-regulated learning skills better.

American Psychological Association (APA) stated that psychology is the learning of thoughts and behavior and highlighted the importance of understanding the behavior (APA, 2010). Behavior is strongly influenced by an individual's internal process and environment. Different types of sports also created different practice behavior, leading to a different learning environment. This implied that environmental factors and sports type have a big role in affecting athletes' practice routines and behavior. Nevertheless, similar research is barely done in different types of sports. Group and individualised sports have different characteristics in their learning process. For example, they can have a different practice schedule and type, which might require more self-regulation effort, or more aspects are needed to gain the most of the practice by initiating optional practice other than the scheduled ones. Hence, it is necessary to understand how the process of self-regulation reflected on athletes' practice behavior in different type of sports.

Englert (2016) stated that there has been no study done on various training contexts and practice conditions. Therefore, the objective of this study is to measure behavior correlation of self-regulated learning in young badminton players in Indonesia. Young and Starkes (2006) also mentioned that self-regulation is an individual process which cannot be measured directly and two sources should be utilised in order to understand the strength of the self-regulatory process: self-report and/or behavioral observation. Since behavior is the main focus of this research, the method of data collection will be the behavioral observation, and other methods will also be utilised to support the analysis of the behavior. This includes the initial process of generating behavioral items for the observation by interviewing experienced coaches and correlating the results with a selfreport from the athletes which will be collected by a questionnaire.

\section{Method}

\section{Study Design}

This research was aimed to measure behavior correlation of self-regulated learning in young badminton players in Indonesia. Therefore, this study is divided into two parts and was delivered between two badminton clubs in different cities in Indonesia. The first part was generating a list of behavioral items in badminton practice with the experienced badminton coaches. A semi-structured interview was conducted with six badminton coaches with coaching experience from five to 20 years $(M=14.3)$. The second part of the study was the observation of the practice behavior of 11 young badminton players within the age range of 12 to 19 years old, using a video-taped practice sessions. After that, the observation results were analysed by correlating them with the self-report done by the players which measured their self-regulated learning. All the institutional ethics approval to work with human participants in this study had been obtained before any of the direct contact with participants was initiated. The whole process was replicated into another badminton club in another city in Indonesia.

\section{Part 1 - Coach Interview}

Participants. The participants of the first part of this research were six experienced male badminton coaches who were coaching the athletes at the time. The coaches, with an average coaching experience of 14 years, voluntarily participated in this study. Each coach was coaching a different division of badminton which consisted of different ages, genders, and players' type of play as well. The demographic details of the coaches are presented in Table 1 .

Procedures. Permission to conduct the research was obtained from the director of the badminton club first. Following this, the researcher contacted the coaches to ask for their consent to participate in this study. They were provided with general information about the research, and what was required from them was confirmed before they signed their consent. Thereafter, each coach was scheduled for an interview session of approximately 45-60 minutes with the researcher.

Instruments. Before the interview, the coaches were given a series of explanations about the concept of self-regulated learning. This was done in layman terms (see Toering et al., 2011, p.114). To deepen the coaches' understanding of self-regulated learning, first they were given the definition of self-regulated learning in a practice context ("self-regulation refers to processes by which individuals control their thoughts, feelings and actions during practice"). After that, they were also provided with the metacognitive ("the regulation of a player's own thoughts during practice") and motivational ("the goals players set for themselves during practice and the effort they are willing 
Table 1

Coach Demographic

\begin{tabular}{lccccc}
\hline Age (year) & $\begin{array}{c}\text { Coaching Experience } \\
\text { (year) }\end{array}$ & Division & $\begin{array}{c}\text { Number of } \\
\text { Players }\end{array}$ & $\begin{array}{c}\text { Players' Age } \\
\text { (year) }\end{array}$ \\
\hline Coach A & 44 & 15 & Women Double & 19 & 15 to 19 \\
Coach B & 41 & 20 & Women Single & 20 & 12 to 15 \\
Coach C & 35 & 15 & Men Double & 30 & 15 to 18 \\
Coach D & 38 & 15 & Men Single & 18 & 15 to 18 \\
Coach E & 28 & 5 & Mixed Double & 24 & 13 to 15 \\
Coach F & 37 & 16 & Men Single & 17 & 12 to 15 \\
\hline
\end{tabular}

to expend to attain these goals") aspects of self-regulated learning. Subsequently, they were requested to describe behaviors that they perceive reflected selfregulation learning.

After the general explanation of self-regulation of learning, the coaches were given open-ended questions about the six aspects of planning, self-monitoring, evaluation, reflection, effort, and self-efficacy. In the last part of the interview, the coaches were asked to describe the behaviors they perceived as reflecting good and poor self-regulation of learning during these three different periods: pre-practice period, during practice, and after practice, respectively. All the answers were also used to check whether or not the coaches had the correct understanding of the concept of self-regulation learning.

Data analysis. The interview results were analysed separately before all of the results were combined into one list of behavioral items. Each item mentioned by the coaches was generated into behavioral items and categorised into the six self-regulation aspects. Those behavioral items were also sorted into either good or poor self-regulated learning behavior to a list of behavioral items for observation.

\section{Part 2 - Behavioral Observation and Self- Report}

Participants. Eleven young badminton players within the age range of 12-19 years old who had done various national competitions were asked for their consent to participate in this study. Informed consent was also given by the parents. All participation was voluntary and they were assured of confidentiality before data collection began. All coaches and players were from the same club for convenient sampling purposes.

Procedures. The selected badminton players gave informed consent and their parents were contacted prior to the behavioral observation. After obtaining parents and players' consent, the researcher recorded each player's whole practice session. Pla- yers were not told of the real purpose of the recording to avoid them showing a social desirability bias. Nevertheless, they were still informed of the practice recording because they were not used to having their practices being recorded and they were told that the recording was for training purposes. After the recording of all 11 players was finished, they were asked to fill out a 46-item Self-Regulation Scale Questionnaire (Toering, Elferink-Gemser, Jonker, Van Heuvelen, \& Visscher, 2012). Players were all not filling out the questionnaire at the same time due to the different practice schedule and free time. Every two players did the questionnaire at the same time while being accompanied by the researcher so they could ask directly if there was any statement they did not understand. At the end of the series of this research, players were told the real purpose of the study and thanked for their participations.

Instruments. The instruments used in this research were behavioural observation and self-regulation scale.

Behavioral observation. A list of behavioral items was generated and operationalised from the coach interview based on six self-regulated learning aspects. A whole practice session from each of the 11 selected players was recorded and analysed. Each behavioral item was scored based on the frequency shown by each player. Every behavior was graded as one each time it was displayed by a player. This ensured whether a certain behavior was shown and how often it was displayed. There was also special scoring applied for certain behavioral items that couldn't be graded by counting frequency.

Self-regulation scale. The badminton players were asked to do a self-report on their own self-regulated learning. The self-report in this research was measured with the 46-item Self-Regulation Scale by Toering et al. (2012) which consists of the same aspects as the ones being asked during the coaches' interview. It consists of planning (eight items), self-monitoring (six items), evaluation (eight items), reflection (five items), effort (nine items), and self-efficacy (ten items). This 
SRS Scale was proven to have a sufficient reliability and validity for measuring self-regulation in the learning context for adolescents aged 12 to 19 years.

Data analysis. The observer counted each behavioral item shown in the recording and then the score was divided by the number of practice sessions attended by each player and recorded by the researcher. Considering the limited time and resources available for the observation, each player was observed for just one practice session (including the pre-practice, during practice, and after practice period). After obtaining the mean score of each player's behavior per aspects of self-regulated learning, they were correlated with the Self-Regulation Scale (SRS) Questionnaire done by the players.

Translation methods. The instruments in this study were translated and adopted into Indonesian using the method of parallel back-translation (Brislin, 1970). Four bilingual individuals who are fluent in both English and Indonesian were employed. First, two individuals translated the instruments from English to Indonesian and the other two who had never seen the original English version of the questionnaire translated them back into English. Both back-translation versions were then checked for the similarities with the original version and the one with a higher similarity level was chosen. Appropriate adjustments and changes were also made based on both versions.

\section{Results}

\section{Coach Interview}

Six expert male badminton coaches with coaching experience of six to 20 years were interviewed. Three of them already had international coaching experience of around three to four years. From the coaches' interview, all coaches came to a similar conclusion about self-regulation. They all agreed that self-regulated players show eagerness in practice, they have initiative and take control of their own training, discipline and enthusiasm. These things reflected in practice behavior such as arriving before the practice starts, focusing on practicing all the programmes made by the coaches, asking for additional practices, and preparing themselves well for the practice (e.g. not forgetting to bring the equipment needed for the practice). The coaches agreed that the metacognitive component of self-regulation associated strongly with how players think and are aware of their own thinking and doing. The motiva- tion component plays a crucial part in players' practice behavior and it also determines the quality of the practice. Those things were revealed in their answers about self-regulation of learning, metacognition, and motivation:

Players who self-regulated their training show spirit in their eyes and eagerness in every practice. They constantly push themselves to their limit and listen to what coaches say to them.

Metacognitive is something that is really new for us yet very important. It is important for players to be aware of what they are thinking and also think carefully about what and why they are doing what they are doing.

Motivation is an important element which determines what kind of attitude a player will show for the practice. A player with high motivation gives more effort and are more focused in their practice.

The coaches also mentioned that there were three types of practices. Several trainings seemed to elicit different responses from players. Coaches mentioned that there were three types of training which consisted of different kinds of exercise: game, techniques, and physical training. Players' performance during practices fluctuates and tends to be unstable. All coaches reported that each training had its own characteristic and most players show similar behavior tendencies over certain types of training. For example, players tend to be excited and more eager during game training rather than technique and physical training. In contrast, physical training seemed to be the practice which most of the players feel reluctant to do. Several coaches added that physical training was the opportunity to determine those players that are really dedicated and motivated and those who are not.

Expert coaches mentioned about 28 behavioral items which represents good and poor self-regulation in badminton practice. However, some of the items were similar to each other or not significantly visible during short period observation. Moreover, due to the inability to retain the audio information from the observation video, only 12 items are visible and observable in their practice as shown in Table 2 . The behavioral items numbered 1 to 9 were representing good self-regulation in practice and three items from number 10 to 12 indicated poor self-regulation behavior. Items which were perceived as good selfregulation behavior will be described first and then items which were predicted as poor self-regulation will 
Table 2

List of Behavioural Items Provided by Expert Coaches

\begin{tabular}{|c|c|c|c|}
\hline No. & Behavioural Item & Aspects* & Operational Definition \\
\hline 1. & $\begin{array}{l}\text { Arrive early for } \\
\text { practice }\end{array}$ & $\begin{array}{l}\text { Planning (6) } \\
\text { Effort (6) }\end{array}$ & $\begin{array}{l}\text { Arrived to the field before the scheduled practice hour: } 0=\text { no, } 1= \\
\text { yes }\end{array}$ \\
\hline 2. & $\begin{array}{l}\text { Stay longer after } \\
\text { practice }\end{array}$ & $\begin{array}{l}\text { Evaluation ( } 3) \\
\text { Effort }(5)\end{array}$ & $\begin{array}{l}\text { Not immediately leaving the field after practice: } 0=\text { no, } 1=\text { yes } \\
\text { Counted if doing at least one of these things: } \\
\text { - Practice on their own } \\
\text { - Watching others practice } \\
\text { - Cleaning up the balls }\end{array}$ \\
\hline 3. & $\begin{array}{l}\text { Start practicing on } \\
\text { their own before the } \\
\text { practice starts }\end{array}$ & $\begin{array}{l}\text { Planning (3) } \\
\text { Effort (5) }\end{array}$ & $\begin{array}{l}\text { Start warming up before the actual practice without being asked, do } \\
\text { practice on their own (e.g. swinging hands, footwork, and other } \\
\text { techniques): } 0=\text { no, } 1=\text { yes }\end{array}$ \\
\hline 4. & $\begin{array}{l}\text { Follow all the } \\
\text { programmes eagerly }\end{array}$ & $\begin{array}{l}\text { Effort (6) } \\
\text { Self-efficacy } \\
(5)\end{array}$ & $\begin{array}{l}\text { Take every movement seriously, seen from their expression and their } \\
\text { movement: } 0=\text { no, } 1=\text { yes }\end{array}$ \\
\hline 5. & $\begin{array}{l}\text { Actively ask } \\
\text { questions/advice } \\
\text { after/during practice }\end{array}$ & $\begin{array}{l}\text { Evaluation (6) } \\
\text { Reflection (6) } \\
\text { Self- } \\
\text { Monitoring (5) }\end{array}$ & $\begin{array}{l}\text { Approach/ask questions to the coach during or after session: asked } \\
\text { for their weaknesses, their timing (in endurance and strength training) } \\
\text { and performance, or asking for additional practice: } 0=\text { no, } 1=\text { yes }\end{array}$ \\
\hline 6. & $\begin{array}{l}\text { Willing to chase the } \\
\text { ball }\end{array}$ & $\begin{array}{l}\text { Self-Efficacy } \\
(4) \\
\text { Effort (6) }\end{array}$ & $\begin{array}{l}\text { Willing to run for the-almost-impossible-ball, quick and enthusiastic, } \\
\text { even if they have to fall or rolling down: } 0=\text { no, } 1=\text { yes }\end{array}$ \\
\hline 7. & $\begin{array}{l}\text { Practice the advice } \\
\text { given to them right } \\
\text { away }\end{array}$ & $\begin{array}{l}\text { Self- } \\
\text { Monitoring (4) } \\
\text { Evaluation (5) }\end{array}$ & $\begin{array}{l}\text { Try immediately after being corrected for their mistake by coach, } \\
\text { making a gesture trying to do the movement according to coach's } \\
\text { feedback: } 0=\text { no, } 1=\text { yes }\end{array}$ \\
\hline 8. & $\begin{array}{l}\text { Keep on practicing } \\
\text { even when the } \\
\text { coach is not looking } \\
\text { /paying attention to } \\
\text { them }\end{array}$ & $\begin{array}{l}\text { Self- } \\
\text { Monitoring (3) } \\
\text { Planning (3) }\end{array}$ & $\begin{array}{l}\text { Not decreasing any effort in doing practice when the coach is looking } \\
\text { away from them / not paying attention to them: } 0=\text { no, } 1=\text { yes }\end{array}$ \\
\hline 9. & $\begin{array}{l}\text { Pay attention when } \\
\text { coach is giving } \\
\text { them feedback }\end{array}$ & $\begin{array}{l}\text { Reflection (4) } \\
\text { Evaluation (4) }\end{array}$ & $\begin{array}{l}\text { Making eye contact with coach, not paying attention to other things } \\
\text { on other field, not talking with their friends while coach is talking: } 0 \\
=\text { no, } 1=\text { yes }\end{array}$ \\
\hline 10. & $\begin{array}{l}\text { Joking around } \\
\text { during practice }\end{array}$ & $\begin{array}{l}\text { Reflection (5) } \\
\text { Self-Efficacy } \\
\text { (3) }\end{array}$ & $\begin{array}{l}\text { Joking during practice with their friend, results in delaying their } \\
\text { practice. Counted when done more than twice in one whole practice: } \\
0=\text { yes, } 1=\text { no }\end{array}$ \\
\hline 11. & $\begin{array}{l}\text { Bargaining/ } \\
\text { complaining }\end{array}$ & $\begin{array}{l}\text { Reflection (3) } \\
\text { Effort (4) }\end{array}$ & $\begin{array}{l}\text { Sigh/showing burdened expression/complain after receiving direction } \\
\text { from coach, or try to bargain when the direction given by coach: } 0= \\
\text { yes, } 1=\text { no }\end{array}$ \\
\hline 12. & $\begin{array}{l}\text { Come to the } \\
\text { practice unprepared }\end{array}$ & Planning (6) & $\begin{array}{l}\text { Left in the middle of practice to get either their water bottle, shoes, } \\
\text { socks, racquet, the grip, or something else that they left behind: } 0= \\
\text { yes, } 1=\text { no }\end{array}$ \\
\hline
\end{tabular}

Note. *Number of coaches mentioned that aspect.

be discussed after.

Several behavioral items were associated with several aspects of self-regulated learning. All expert coaches agreed that "arrive early for practice" reflected good planning and effort. When players come to the practice before the schedule, it means they planned the practice ahead in their own agenda and indicated good planning. Some players came to the practice just in time with the schedule, yet players with good self-regulation were willing to give effort by coming early to practice.
Coaches perceived "stay longer after practice" as an example of good evaluation and effort. Players evaluate their own practice and give effort on working on their weaknesses by having additional practice on their own. Watching others' practice can also help players evaluate and reflect back on their own practice, finding their strength and weaknesses to improve. Coaches also regarded the simple behavior of doing the cleaning up of balls regardless of their turn to clean up as a reflection of good effort and responsibility. 
Expert coaches agreed that players with good self-regulation were high in initiative. They did not wait for coach's instruction to do something they regarded as their own need. Three expert coaches agreed that "start practicing on their own before the practice starts" was the expression of planning and more coaches also agreed that it reflects the effort aspects of self-regulation. Those players did not waste their time while waiting for the practice as they already planned to do their own practice beforehand. They give effort in doing the exercise, warming up, or doing preparation on their own without needing to be asked by the coach.

All expert coaches agreed that physical training was the time when the effort of the players was being challenged the most. It will clearly show which players give the maximum effort of themselves and the willingness to push beyond their limit. Moreover, five coaches also assumed players' eagerness during training as an example of self-efficacy. Players who eagerly follow the whole training programme during the practice show a serious and dedicated expression. They push themselves to the limit even though they feel tired because they believe in their ability to meet their personal target or achieve the target that their coach had given to them.

"Actively ask questions or advice after or during training" was regarded as the expression of evaluation, reflection, and self-monitoring aspects of selfregulated learning. Self-regulated players evaluate their own weaknesses and reflect on how they can improve better by asking the coach about things related to their performance during session breaks or after a practice session ended. They also actively seek advices about their own movement or techniques without waiting for the coach to give them feedback, because they want to do everything right. That kind of behavior was perceived by the coaches as the indicator of self-monitoring their own progress. However, some coaches noted that the depth of the question was also important. Asking the same questions several times without showing any significant improvement was not perceived as good reflection: "Some players could be asking the same questions several times because they wanted to get the coach's attention, not with the intention of fixing their weaknesses. Especially the kids, often asking the instructions to be repeated just so the coach will pay attention to them."

Players with good self-regulation did not entirely depend on the coach's attention to them. They "keep on practicing even when the coach is not looking or paying attention to them" by giving their maximum effort in the practice. Expert coaches perceived this item as good planning and self-monitoring aspects. They planned their practices well and stuck to accomplishing their target while self-monitoring their performance regardless of the coach's attention because they realised that they were doing that for their own improvement.

"Willing to chase the ball" was appointed by all coaches as an example of good effort. Players who showed effort was mainly seen from their willingness to chase the ball from one to opposite corner, even if they had to fall down and roll around. This behavior item showed not only during the game practice, but also the technical practice. This was especially seen during drill practice when players need to maintain speed and agility to catch all the balls back and forth from one to opposite corner for some period of time. Several coaches also indicated that this behavior reflected self-efficacy of the players: "They are quick at standing up after falling down and instantly back to the stance for receiving the next ball. They give no room to rest for that 30 seconds to one minute of drilling because they know they can do it."

Most coaches assumed that "practice the advice given to them right away" is an expression of good evaluation and self-monitoring. Players with the good evaluation aspect of self-regulation have a quick response to the advice and feedback given by the coach. This related with item "pay attention when coach is giving them feedback" which is associated with reflection and evaluation aspects. They paid attention to what the coach was saying and tried to practice the feedback right away. They did not get distracted by playing with their friends or looking around. These players looked at the coach and focused on the things their coach was saying during the briefing and evaluation.

"Come to the practice unprepared" was mentioned as an example of poor planning by all the expert coaches. They stated that: "Players should prepare everything before they come to the practice, like the grip, water bottle, shoes, racquet, and spare t-shirts. You can tell that they are not really prepared for the practice when they left the practice field often to take whatever they left behind." Poor planning resulted in less focus in the practice because they wasted time going back and forth for the things they forgot when they could actually get more from the practice.

The poor reflection aspect of self-regulation was reflected by "bargaining/complaining" and "joking 
Table 3

Mean, Standard Deviation, and Scores Range of Observed Behavioural Items

\begin{tabular}{lcr}
\hline Behavioural Items: Good Self-Regulated Learning behaviours & $\boldsymbol{M}(\boldsymbol{S D})$ & Range of Scores \\
\hline Arrive early for practice & $1.00(0.00)$ & $0.00-1.00$ \\
Stay after practice more & $0.78(0.42)$ & $0.00-1.00$ \\
Start practicing on their own before the practice starts & $0.15(0.36)$ & $0.00-1.00$ \\
Eagerness & $1.00(0.00)$ & $0.00-1.00$ \\
Actively ask questions/advice after/during practice & $0.04(0.19)$ & $0.00-1.00$ \\
Willing to chase the ball & $1.00(0.00)$ & $0.00-1.00$ \\
Practice the advice given to them right away & $0.96(0.19)$ & $0.00-1.00$ \\
Keep on practicing even when the coach is not looking/paying attention to & $0.96(0.19)$ & $0.00-1.00$ \\
them & $1.00(0.00)$ & $0.00-1.00$ \\
Pay attention when coach is giving feedback & $\boldsymbol{M ( S D )}$ & Range of Scores \\
\hline Behavioural Items: Poor Self-Regulated Learning behaviours & $0.15(0.36)$ & $0.00-1.00$ \\
Joking around during practice & $0.07(0.27)$ & $0.00-1.00$ \\
Bargaining/complaining & $0.00(0.00)$ & $0.00-1.00$ \\
Come to the practice unprepared & &
\end{tabular}

around during practice". Players with poor effort usually complained or tried to bargain with the coach when they were given a training programme because they were reluctant to push themselves to their limit. Expert coaches also perceived players who were joking around too much during practice as having poor self-efficacy because they saw themselves as unable to fulfil the target given so they were looking for distraction from the actual tasks. They could not maintain their focus on practice and took the practice less seriously.

In summary, effort was the most represented aspect of self-regulated learning in the behavioral items mentioned by coaches, while the least were selfmonitoring and self-efficacy. Most coaches mentioned several overt behavioral items related to this aspect as shown in Table 2. Effort was represented in six behavioral items whereby most of the coaches agreed on each item. This indicated that effort was regarded as relatively more concrete and easier to understand by the coaches compared to other aspects, considering this was the first time they heard of the self-regulation of learning concept. Furthermore, effort was associated with working hard which coaches emphasised to their players in order to maximise the result of the practices. This matched the result that coaches always encouraged their players to constantly give extra effort and push them to their limit. Coaches also had a good enough understanding of the self-regulation of learning concept so that they were able to classify those behavioral items during practice into good and poor categories. Behavioral items were then observed within the selected players' practices and compared to the self-regulation questionnaire done by each player to see how they were related.

\section{Behavioral Correlates}

The mean, standard deviation, and range of scores of the behavioral items mentioned by the coaches are shown in Table 3. Each item was scored over three practices of game training, physical training, and technique training in badminton. There were several items that were constantly seen in the players during the observed practices. Those items were "arrive early for practice", "eagerness", "willing to chase the ball", and "pay attention when coach is giving feedback". The item that appeared the least was the one under the poor self-regulation behavior according to expert coaches: "come to the practice unprepared". Yet, within the category of good selfregulation of learning the item that was seen the least was "actively ask questions/advice after during practice".

The behavioral correlates of the Spearman correlation results in Table 4 showed that "stay longer after practice" correlated with the total self-regulation. Only effort and self-efficacy aspects were associated with the behavioral items mentioned by the expert coaches, while the other aspects had no significant association with the rest of the behavioral items on the list. Effort was linked with "arrived early for practice", "eagerness", "willingness to chase the ball", and "pay attention when coach is giving them feedback". "Stay after practice more" and "start practicing on their own before the practice starts" were linked with self-efficacy. Item "keep on practicing even when the coach is not paying attention to them" was correlated with both effort and self- 
Table 4

Spearman Correlation between SRS Questionnaire and Behavioural Observation

\begin{tabular}{|c|c|c|c|c|c|c|c|}
\hline & Planning & $\begin{array}{c}\text { Self- } \\
\text { Monitoring }\end{array}$ & Effort & $\begin{array}{c}\text { Self- } \\
\text { Efficacy }\end{array}$ & Evaluation & Reflection & Total \\
\hline $\begin{array}{l}\text { Item 1: Arrived early for } \\
\text { practice }\end{array}$ & & & $.699^{*}$ & & & & \\
\hline $\begin{array}{l}\text { Item } 2 \text { : Stay longer after } \\
\text { practice }\end{array}$ & & & & $.647^{*}$ & & & $.667^{*}$ \\
\hline $\begin{array}{l}\text { Item } 3 \text { : Start practicing } \\
\text { on their own before the } \\
\text { practice starts }\end{array}$ & & & & $.782^{* *}$ & & & \\
\hline Item 4 : Eagerness & & & $.699^{*}$ & & & & \\
\hline $\begin{array}{l}\text { Item } 6 \text { : Willing to chase } \\
\text { the ball }\end{array}$ & & & $.699^{*}$ & & & & \\
\hline $\begin{array}{l}\text { Item } 8 \text { : Keep on } \\
\text { practicing even when the } \\
\text { coach is not } \\
\text { looking/paying attention } \\
\text { to them }\end{array}$ & & & $.639^{*}$ & $.614^{*}$ & & & \\
\hline $\begin{array}{l}\text { Item } 9 \text { : Pay attention } \\
\text { when coach is giving } \\
\text { them feedback }\end{array}$ & & & $.699^{*}$ & & & & \\
\hline
\end{tabular}

efficacy. There was no significant negative correlation found between behavioral items and both the self-regulation of learning total and aspects.

As for the completion of the self-regulated learning questionnaire, the process was done by two players at a time. The demographic data found that all the badminton players needed to give up their formal education when they entered the club because of the packed practice schedules throughout the week. Thus, whether or not they got previous formal education depended on how old they were when they entered the club. There were many questions that arose during the process regarding several statements in the questionnaire, especially by the players within the age range of 12 to 17 , and with no proper formal education background. Nevertheless, no similar problem was found with the players aged 18 years above and with those who previously got formal education before entering the club.

\section{Discussion}

This study was focused on measuring behavioral correlates in young Indonesian badminton athletes' practice. The first part of this study was interviews with expert badminton coaches to generate the list of behavioral items which will be observed in the next part of the study. After the interview, observation of players was done within three practices and they were asked to fill a self-report on their own selfregulated learning in the form of a questionnaire. Subsequently, the observation result was correlated with the self-regulation of learning questionnaire done by the observed players. In this part, the expert coach interviews will be discussed first, followed in the next part by the results of behavioral correlates and general discussion.

\section{Coach Interview}

Expert coaches agreed that self-regulated learning behavior in general was shown in players' proactive behaviors. They perceived that players with good self-regulation of learning would create an optimal environment to accommodate their learning, being focused and responsible for their own practice. These aspects were similar with some other similar sports field studies. A study done by Harwood (2008) on coach efficacy within soccer players' skills training enhancement founded the ' $5 \mathrm{Cs}$ ' design. It stood for commitment, communication, concentration, control, and confidence. Those elements matched the self-regulation of learning components mentioned by the coach interview in this study.

Harwood (2008) explained the behavioral examples of the '5Cs' concept in communication reflected in asking questions to the coach, commitment skills showed in increased effort, listening to the instructions attentively showed concentration, control 
was perceived in how someone presented their positive body language, and how attending practice displayed confidence. These behavioral examples were also found in items mentioned by the expert badminton coaches, for instance, "pay attention when coach is giving them feedback", "eagerness in following the practices", and "arrived early for practice". Item "start practicing on their own before the practice starts" mentioned in this study was similar to item in the previous study on soccer players in Dutch done by Toering et al. (2011) about "works on improvement of his weak points during the 30 minutes before start of practice session". Several other items such as "verbally approaches coach during instruction", "verbally approaches coach during exercise", and "verbally approaches coach after exercise" were also replicated in one behavioral item "actively ask questions/advice after/during practice" within this study.

Another similar study on several soccer and rugby expert coaches in the United Kingdom by Oliver, Hardy, and Markland (2010) also highlighted the preparation aspect of the players, such as arriving well-prepared with "the correct kit for training" and being "on time, or even early" to the practice. Those things were in accordance with items mentioned by the expert badminton coaches in this study, for example, they regarded item "come to the practice unprepared" as a player who had poor self-regulation of learning. Coaches also emphasised that arriving on time or before the practice started as a predictor of good planning. This proved that behaviors which reflected self-regulation of learning had a universal concept and characteristic across different field sports, even in different countries as well.

Despite the commonalities found between this study and previous ones, there were some issues regarding the interpretation of items related with players' verbal approach to coaches. In general, the coaches agreed that being proactive and actively asking questions were things they expect from their players to show more. As Karabenick and Newman (2009) mentioned, a strong metacognitive strategy of helpseeking was displayed over the act of asking questions to others. Nevertheless, the coaches also highlighted the importance of question quality asked by the players during the practice. They assumed that most of the questions asked by the players were unnecessary because they often did not listen to the instructions well and just repeated the same questions. Players ask questions because they want to get the attention from the coach instead of working on their self-monitoring and evaluation. That kind of behavior was perceived as lack of attention by several coaches in previous findings by Morgan (2004), which was also addressed as a maladaptive behavior during practice.

There were also some concerns regarding the behavior displayed by the players. It is important to notice that there are two possible elements in analysing players' different behavior during three different kinds of practices, as mentioned by the coaches. Behavior displayed by players could be affected by trait and/or state elements. Players' traits could influence their tendency to behave in a certain way (e.g. some players might be more active than the other players and tend to move around a lot), nonetheless, some behavioral items displayed during certain practice might differ from another practice (e.g. players are more eager and enthusiastic during game practice rather than physical). Hence, it is also possible that some behaviors consist of both characteristics. For example, a player might tend to always give her best in every practice, yet, her eagerness in the actual practice could depend on her state at that time such as her mood, previous major event, her physical condition, etc. This was also supported by the study conducted by Oliver, Hardy, and Markland (2010) which mentioned that variation in internal and external factors might possibly cause a change in players' practice behavior from one to another practice session.

One important thing for the coaches to note is they should be aware that players who showed good self-regulated learning behavior during practices might not necessarily perform the best among the others. The behavior list developed from the interviews was not the list to identify the best badminton player. As Young and Starkes (2006) had previously done in a similar study with the swimmers, this study would help coaches identify behaviors which can improve players' habits during practice and help players to develop more self-regulated practice.

\section{Behavioral Correlates}

Previous study in youth elite soccer players done by Toering et al. (2011) found that the behavioral items which correlated mostly with self-regulation was "coaching teammate (with gesture)". Considering soccer as a group sport, that item strongly related with how good self-regulated players within group sports most likely behave. Different results were shown in this study as badminton is regarded as an 
individual sports. The behavioral item that correlates strongly with total self-regulation was "stay longer after practice" which relates more to the personal effort by players in their own practice. This also implied that players with good self-regulation are more concerned with their own practice rather than giving more attention to other people's practice.

As pointed out by Zimmerman (1990) there are differences between team and individual sports, involving: (1) strategies selection on self-regulated learning; (2) capability on receiving learning feedback; and (3) interdependent motivational process. This explained the differences in observed behavioral items with players' self-regulated learning. Higher need of high level achievement was also more subtle in individual compared with group sports since it is more influenced by individual performance rather than an entire group performance (Elferink-Gemser, Visscher, \& Lemmink, 2008). Players in team sports rely more on the performance and behavior of the entire team which might result in less ambition for personal achievement than players who play in individual sports. This explains how players in individual sports score higher in self-regulation skills, especially effort and planning aspects (Jonker, Elferink-Gemser, \& Visscher, 2010).

There were only two aspects associated with the behavioral items from six aspects of self-regulation of learning: effort and self-efficacy. Effort was the manifestation of motivational outcome and self-efficacy was the one for motivational belief. As Pintrich and Schunk (2002) explained, motivational aspects play a significant role in the selection of cognitive and metacognitive strategy in self-regulation of learning. Furthermore, the metacognitive component of expert learner's regulatory process consisted of planning, self-monitoring, evaluation, and reflection aspects (Ertmer \& Newby, 1996). Although the results showed that none of the metacognitive component was significantly associated with any of the behavioral items, both the observation and self-report questionnaire of the observed players still indicated moderately good self-regulation. Therefore, it is important to further analyse the relationship between the aspects and behavioral items in order to see the complete picture of how Indonesian young badminton players self-regulate their learning.

Several behaviors of good regulation of learning were constantly seen during three observed practices, such as "arrive early for practice", "eagerness", "willing to chase the ball", "pay attention when coach is giving feedback", and never "come to the prac- tice unprepared". This showed that players with good self-regulation constantly came early and prepared, but they were not always doing their own practice during the spare time before the practice $(M=0.15)$. Not all players with good self-regulation stayed longer after practice $(M=0.78)$, in this case they might have stayed longer in the field but not doing any of the practice on their own, watching others practice, nor cleaning up the balls. Combined with the result of least seen behavior which was "actively ask questions/advice after/during practice" $(M=0.04)$ the data described common characteristics of the observed players. They were motivated and eager for the practice and training designed by the coach, however, players were lacking in initiative and less proactive regarding their own practice.

This result was contradictory with the coaches' expectation of good self-regulated players, which was being proactive and taking initiative for their own learning. Players were more into doing what is instructed or what they had been told to do. This reflected the lack of 'seeking information to improve' as described by Oliver et al. (2010) which is crucial for athletes to gather and utilise information in order to improve their performance. This area consisted of asking and answering questions, self-evaluation, feedback-seeking behavior, and improving performance using negative feedback. Behavioral correlate results of this study showed no significant correlation between the behavioral items with self-regulation aspects such as planning, self-monitoring, evaluation, and reflection which were all included in the metacognitive component. Not only did the players show the least of those metacognitive aspects during the observation and their self-regulation questionnaire, but the list of behavioral items generated by the coaches were also not significantly related with those aspects.

Players were programmed to obey orders and follow instructions. Furthermore, the study by Holt and Dunn (2004) revealed a similar situation where players needed to do everything they were told to. The coach's role was certainly important, as they were responsible for generating the whole practice schedule and even assigning goals. It was also an important aspect as the source of self-efficacy for players because it conveyed the coach's belief in their ability (Bandura, 1993). It explained how the self-efficacy aspect was significantly correlated with the behavioral items. Furthermore, the tendency of giving high effort in practice was in accordance with the overall result of players' behavior which supports this 
cycle to keep going.

However, this could be the main reason for the lack of metacognitive process in players. They were not used to thinking critically about what they actually need in order to maximise their own potential and how they could get it. They were getting used to of having everything prepared for them, so they were not trained to think. This then led to the lack of initiative and proactive behavior of seeking information. In addition, coach's responses to players' questions were also not promoting the desirable behavior as they often perceived players' questions as their way of getting the coach's attention rather than trying to improve themselves. This also indicated that the attention-seeking behavior tends to be higher in individual sports players, especially the young ones, as the competition was more about personal achievement between the players themselves.

\section{Limitations and Future Studies}

There was a possibility that the behavior mentioned by the coaches was not observed during the right type of practice. Not all of the behavioral items generated from the coach interviews were relevant to all types of practice. Certain behaviors might be more prominent in one practice, but not in another, and vice versa. It is important to consider the variation in internal and external factors in players' behavior for each practice session (Oliver et al., 2010). Furthermore, there was a possibility of error within the completion of the self-regulated learning questionnaire done by the young players within the age range of 12 to 17. The amount and frequency of questions asked during the completion of the questionnaire indicated that the questionnaire was not suitable for young players below 17 or those with limited or no formal education background. Future research should address these issues in order to gain a more complete and precise impression of players' self-regulation of learning skills within the practice context.

\section{Conclusion}

The present study examined the behavioral correlate of self-regulated learning aspects within Indonesian young badminton players' practice behavior. Twelve behavioral items were generated by six expert coaches and correlated with a self-regulation of learning questionnaire completed by 11 players. The coaches perceived some behavioral items as the indicator of good and poor self-regulated learning in the practice, with effort as the most reflected aspect in the behavioral items. Moreover, the behavioral correlate results also showed that effort was the most correlated aspect with players' observation and selfreport. In general, the scores showed that players exhibit good self-regulated learning in their practice. However, players were lacking in metacognitive aspects of self-regulated learning despite the high effort shown in the result. This led to the lack of initiative and less proactive behavior in managing their own learning process, which was not consistent with the concept of self-regulated learning mentioned by the coaches and previous studies (Harwood, 2008; Oliver et al., 2010; Toering et al., 2011).

Taken together, this study highlighted that the effort aspect of self-regulated learning was really prominent in both coaches and players. The players were high in effort and tended to follow instructions well, which showed good qualities of professional players. Even so, coaches should pay more attention to the metacognitive components in self-regulation of learning in order to properly develop good self-regulated learning skills and maximise their players' potential. Therefore, it is important to gain a better and more complete impression of players' practice behavior. In consideration of that, further study should address the issue of behavioral observation in different types of practice and adopt a better suited selfregulation of learning questionnaire for young players under certain circumstances.

\section{Acknowledgements}

The author was grateful for the help and support from EXIST Badminton club and Alan Budikusuma, badminton gold medalist in the 1992 Summer Olympic Games (officially known as the Games of the XXV Olympiad) and previous international badminton player from Indonesia. It was an honour to be granted a rare opportunity to work with one of the best three badminton clubs in Indonesia who are really open-minded and supportive during the entire process of this study.

\section{References}

American Psychological Association (APA). (2010). How does the APA define "psychology"? Retrieved from American Psychological Association website: http://www.apa.org/support/about/apa/ psychology.aspx\#answer 
Bandura, A. (1993). Perceived self-efficacy in cognitive development and functioning. Educational Psychologist, 28, 117-148.

Brislin, R. W. (1970). Back-translation for cross-cultural research. Journal of Cross-Cultural Psychology, 1(3), 185-216. http://dx.doi.org/10.1177/13 5910457000100301

Baumeister, R. F., \& Vohs, K. D. (2004). Handbook of self-regulation: Research, theory, and applications. New York: Guilford Press.

Berliner, D. C. (1994). Expertise: The wonder of exemplary performances. In J. N. Mangerieri \& C. Collins Block (Eds.), Creating powerful thinking in teachers and students: Diverse perspectives (pp. 161-186). Orlando, FL: Harcourt Brace.

Cleary, T. J., \& Zimmerman, B. J. (2001). Self-regulation differences during athletic practice by experts, non-experts, and novices. Journal of Applied Sport Psychology, 13(2), 185-206. http://dx. doi.org/10.1080/104132001753149883

Elferink-Gemser, M. T., Visscher, C., \& Lemmink, K. A. P. M. (2008). Differences in psychological skills between elite and sub-elite youth athletes. Journal of Physical Education and Sport Sciences, 4, 95-105.

Englert, C. (2016). The strength model of self-control in sport and exercise psychology. Frontiers in Psychology, 7, 314. http://dx.doi.org/10.3389/fpsyg. 2016.00314

Ericsson, K. A., Krampe, R. T., \& Tesch-Römer, C. (1993). The role of deliberate practice in the acquisition of expert performance. Psychological Review, 100(3), 363-406. http://dx.doi.org/10.103 7//0033-295x.100.3.363

Ertmer, P. A., \& Newby, T. J. (1996). The expert learner: Strategic, self-regulated, and reflective. Instructional Science, 24(1), 1-24. http://dx.doi.org/ $10.1007 / \mathrm{bf00156001}$

Harwood, C. (2008). Developmental consulting in a professional football academy: The 5Cs coaching efficacy program. The Sport Psychologist, 22(1), 109-133. http://dx.doi.org/10.1123/tsp.22.1.109

Holt, N. L., \& Dunn, J. G. (2004). Toward a grounded theory of the psychosocial competencies and environmental conditions associated with soccer success. Journal of Applied Sport Psychology, 16 (3), 199-219. http://dx.doi.org/10.1080/1041320 0490437949

Hong, E., \& O'Neil, H. F. (2001). Construct validation of a trait self-regulation model. International Journal of Psychology, 36(3), 186-194. http://dx.doi. org/10.1080/ 00207590042000146
Jonker, L., Elferink-Gemser, M. T., \& Visscher, C. (2010). Differences in self-regulatory skills among talented athletes: The significance of competitive level and type of sport. Journal of Sports Sciences, 28(8), 901-908. http://dx.doi.org/10.1080/02 640411003797157

Karabenick, S. A., \& Newman, R. S. (2009). Seeking help: Generalizable self-regulatory process and social-cultural barometer. In M. Wosnitza, S. A. Karabenick, A. Efklides, \& P. Nenninger (Eds.), Contemporary motivation research: From global to local perspectives (pp. 25-48). Ashland, $\mathrm{OH}$ : Hogrefe Publishing.

Kitsantas, A., \& Zimmerman, B. J. (2002). Comparing self-regulatory processes among novice, nonexpert, and expert volleyball players: A microanalytic study. Journal of Applied Sport Psychology, 14(2), 91-105. http://dx.doi.org/10.1080/1041320 0252907761

Morgan, R. N. (2004). Interactions between personality and psychological skills on training behaviours in Rugby Union (Unpublished master's thesis). Bangor University, Wales.

Oliver, E. J., Hardy, J., \& Markland, D. (2010). Identifying important practice behaviours for the development of high-level youth athletes: Exploring the perspectives of elite coaches. Psychology of Sport and Exercise, 11(6), 433-443. http://dx.doi. org/10.1016/j.psychsport.2010.05.004

Pintrich, P. R., \& Schunk, D. H. (2002). Motivation in education: Theory, research and applications (2nd ed.). Englewood Cliffs, NJ: Prentice Hall Merrill.

Schmeichel, B. J., \& Baumeister, R. F. (2004). Selfregulatory strength. In R. F. Baumeister \& K. D. Vohs (Eds.), Handbook of self-regulation: Research, theory, and applications (pp. 84-98). New York: Guilford Press.

Tedesqui, R. A. B., \& Young, B. W. (2015). Perspectives on active and inhibitive self-regulation relating to the deliberate practice activities of sport experts. Talent Development and Excellence, 7, 29-39.

Toering, T., Elferink-Gemser, M., Jordet, G., Jorna, C., Pepping, G., \& Visscher, C. (2011). Self-regulation of practice behaviour among elite youth soccer players: An exploratory observation study. Journal of Applied Sport Psychology, 23(1), 110-128. http://dx.doi.org/10.1080/10413200.2010.534544

Toering, T., Elferink-Gemser, M. T., Jonker, L., Van Heuvelen, M. J., \& Visscher, C. (2012). Measuring self-regulation in a learning context: Reliability and validity of the self-regulation of learning self- 
report scale (SRL-SRS). International Journal of Sport and Exercise Psychology, 10(1), 24-38. http:// dx.doi.org/10.1080/1612197x.2012.645132

Toering, T., \& Jordet, G. (2015). Self-control in professional soccer players. Journal of Applied Sport Psychology, 27(3), 335-350. http://dx.doi.org/10. 1080/10413200.2015.1010047

Toering, T. T., Elferink-Gemser, M. T., Jordet, G., \& Visscher, C. (2009). Self-regulation and performance level of elite and non-elite youth soccer players. Journal of Sports Sciences, 27(14), 1509-1517. http://dx.doi.org/10.1080/02640410903369919

Young, B. W., \& Starkes, J. L. (2006). Coaches' perceptions of non-regulated training behaviours in competitive swimmers. International Journal of Sports Science and Coaching, 1(1), 53-68. http:// dx.doi.org/10.1260/174795406776338427

Zimmerman, B. J. (1990). Self-regulated learning and academic achievement: An overview. Educational Psychologist, 25(1), 3-17. http://dx.doi.org/10.12 07/s15326985ep2501_2

Zimmerman, B. J. (2006). Development and adaptation of expertise: The role of self-regulatory processes and beliefs. In K. A. Ericsson, N. Charness, P. J. Feltovich, \& R. R, Hoffman (Eds.), The Cambridge handbook of expertise and expert performance (pp. 705-722). http://dx.doi.org/10.1017/c bo9780511816796.039 